\title{
Short communication: Addition of varying amounts of sodium bicarbonate to colostrum replacer: Effects on immunoglobulin G absorption and serum bicarbonate in neonatal calves ${ }^{1}$
}

\author{
R. G. Cabral, ${ }^{\star}$ C. E. Chapman, ${ }^{\star}$ D. M. Haines, $†$ A. F. Brito, ${ }^{\star}$ and P. S. Erickson ${ }^{\star 2}$ \\ *Department of Biological Sciences, University of New Hampshire, Durham 03824 \\ †Department of Veterinary Microbiology, Western College of Veterinary Medicine, University of Saskatchewan, Saskatoon, SK, Canada S7N 5B4
}

\begin{abstract}
Fifty-two dairy calves were blocked by birth date and, within each block, randomly assigned to 1 of 4 treatments to investigate the effects of incremental levels of sodium bicarbonate $\left(\mathrm{NaHCO}_{3}\right)$ on IgG metabolism. Treatments were (1) colostrum replacer $(\mathrm{CR})+0 \mathrm{~g}$ of $\mathrm{NaHCO}_{3}$ (control); (2) $\mathrm{CR}+15 \mathrm{~g}$ of $\mathrm{NaHCO}_{3}$; (3) $\mathrm{CR}+30 \mathrm{~g}$ of $\mathrm{NaHCO}_{3}$; or (4) $\mathrm{CR}+45 \mathrm{~g}$ of $\mathrm{NaHCO}_{3}$. Calves were fed colostrum replacer $(>200 \mathrm{~g}$ of $\operatorname{IgG}$ ) in one feeding within 45 min of birth $(0 \mathrm{~h})$ and $2 \mathrm{~L}$ of milk replacer at $12,24,36$, and $48 \mathrm{~h}$. Only calves born in calving pens from multiparous cows with no dystocia were used in this study. Blood samples were taken at $0,6,12,24$, and $48 \mathrm{~h}$ postpartum, and serum was analyzed for IgG using radial immunoassay and bicarbonate using spectrophotometry. Feeding increasing levels of sodium bicarbonate had negative linear effects on IgG concentration, IgG apparent efficiency of absorption, and IgG area under the curve, primarily due to the effect of the highest dose of $\mathrm{NaHCO}_{3}(45$ g). Sodium bicarbonate treatments had no effect on serum bicarbonate concentration. However, area under the curve of serum bicarbonate increased linearly with the amount of $\mathrm{NaHCO}_{3}$ fed.
\end{abstract}

Key words: calf, colostrum replacer, immunoglobulin $\mathrm{G}$, sodium bicarbonate

\section{Short Communication}

Calves are born hypogammaglobulinemic due to the synepithelialchorial placenta that prevents maternal immunoglobulin transfer to the fetus. Colostrum is the first mammary secretion and provides, through passive transfer, immunoglobulins, predominantly from the $\mathrm{IgG}_{1}$ subclass, which are essential for the health and

\footnotetext{
Received February 4, 2011.

Accepted July 5, 2011.

${ }^{1}$ This is Scientific Contribution number 2446 from the New Hampshire Agricultural Experiment Station.

${ }^{2}$ Corresponding author: peter.erickson@unh.edu
}

well-being of the neonate (Butler, 1969). Serum concentrations of $\operatorname{IgG} \geq 10.0 \mathrm{~g} / \mathrm{L}$ are indicative of adequate passive transfer (NAHMS, 2007). Inadequate passive transfer has resulted in reduced growth rates; increased risks of diseases, death, and early culling; and decreased milk production in the first lactation (Smith and Foster, 2007; Beam et al., 2009). Therefore, it is crucial that calves receive colostrum immediately after birth to maximize the passive transfer of IgG while the small intestine is able to absorb intact Ig. Sodium bicarbonate added as a buffer to fermented colostrum increased the serum IgG concentration in neonatal calves compared with those fed fermented colostrum only (Foley and Otterby, 1978). Feed intake was improved when acidified (Eppard et al., 1982) or fermented (Jenny et al., 1984) colostrum was supplemented with $\mathrm{NaHCO}_{3}$. Sodium bicarbonate also has bacteriostatic effects, inhibiting the growth of Escherichia coli 0111 in human milk (Bullen et al., 1972) and bovine colostrum (Griffiths and Humphreys, 1977). Recently, Morrill et al. (2010) reported that supplementing colostrum replacer (CR) with $\mathrm{NaHCO}_{3}$ increased the serum concentration of IgG compared with $\mathrm{CR}$ alone. However, the optimum dose of $\mathrm{NaHCO}_{3}$ that maximizes IgG absorption has not been determined. We aimed to explore the effect of supplementing $\mathrm{CR}$ with increasing levels of $\mathrm{NaHCO}_{3}$ on IgG concentration, and on the apparent efficiency of absorption (AEA) of IgG.

This experiment was reviewed and approved by the University of New Hampshire Institutional Animal Care and Use Committee. Fifty-two Holstein calves born from multiparous cows were used in this study. Calves were blocked by birth date and, within each block, randomly assigned to 1 of 4 treatments as follows: (1) CR $+0 \mathrm{~g}$ of $\mathrm{NaHCO}_{3}$ (control); (2) $\mathrm{CR}+15 \mathrm{~g}$ of $\mathrm{NaHCO}_{3}$ (15-g treatment); (3) CR $+30 \mathrm{~g}$ of $\mathrm{NaHCO}_{3}$ (30-g treatment); or (4) $\mathrm{CR}+45 \mathrm{~g}$ of $\mathrm{NaHCO}_{3}$ (45-g treatment). The $\mathrm{pH}$ of the reconstituted $\mathrm{CR}$ with or without $\mathrm{NaHCO}_{3}$ was measured using a $\mathrm{pH}$ meter (Orion 230A pH Meter, Thermo Fisher Scientific Inc., Beverly, MA).

Calves were removed from their dams within $30 \mathrm{~min}$ after birth and weighed on a platform scale (Salter 
Scales, Fairfield, NJ), and their navels were dipped in $7 \%$ iodine. Calves were then placed in a naturally ventilated enclosed calf room and individually housed in pens $(1 \times 2.15 \mathrm{~m})$ bedded with kiln-dried sawdust where they remained for the duration of the study ( 48 h). Calves were assigned a dystocia score of 1 to 3 based on the difficulty of the calving: 1 = unassisted calving, $2=$ assisted easy calving, or $3=$ assisted difficult calving (Morrill et al., 2010). Only calves with a dystocia score of 1 or 2 were used in the current study. All calves received 1 feeding of 2 sachets of Land O'Lakes Colostrum Replacement (Saskatoon Colostrum Co., Saskatoon, SK, Canada) containing $>100 \mathrm{~g}$ of $\mathrm{IgG} /$ sachet (total amount of IgG fed $>200 \mathrm{~g}$; Table 1 ) within 45 min of birth (referred to as $0 \mathrm{~h}$ ) using nipple bottles. If the entire volume was not consumed in the first feeding, the $\mathrm{CR}$ was kept warm and reintroduced $1 \mathrm{~h}$ later. If the remaining $\mathrm{CR}$ was not consumed in the second feeding, it was administered to the calf via esophageal tube. For all subsequent feedings, nonmedicated milk replacer (340 g; Blue Seal Feeds Inc., Londonderry, NH) was reconstituted with $2 \mathrm{~L}$ of water and fed to calves at $12,24,36$, and $48 \mathrm{~h}$ after birth. Samples of both $\mathrm{CR}$ and milk replacer were submitted to Agri-King (Fulton, IL) for nutrient analysis: CP (method 990.03; AOAC, 2002) and minerals ( $\mathrm{Ca}, \mathrm{P}, \mathrm{Mg}, \mathrm{K}, \mathrm{Na}$, and $\mathrm{Fe}$; method 985.01; AOAC, 2002). Concentration of total fatty acids was determined by saponification with $\mathrm{KOH}$ in ethyl alcohol. Fatty acids were then liberated from the soaps with $\mathrm{HCl}$ and extracted with petroleum ether (AOAC, 1995). Lactose was determined using method 984.22 (AOAC, 2002) with the following modifications: flow rates through the HPLC (Beckman, Fullerton, $\mathrm{CA}$ ) were $1 \mathrm{~mL} / \mathrm{min}$, melibiose was the internal standard, and evaporative light scattering detection was used instead of a refractive index. Nutrient analyses of $\mathrm{CR}$ and milk replacer are presented in Table 1.

Blood samples were collected into 7-mL Vacutainer tubes (Kendall, Mansfield, MA) via jugular venipuncture using a 22-gauge needle before the initial feeding of $\mathrm{CR}$ and at $6,12,24$, and $48 \mathrm{~h}$ after birth. The blood collected was allowed to clot at room temperature for no longer than $1 \mathrm{~h}$ followed by centrifugation (CentraMP4R; International Equipment Company, Needham Heights, MA) at $1,310 \times g$ at $25^{\circ} \mathrm{C}$ for $20 \mathrm{~min}$. The serum was harvested and stored at $-20^{\circ} \mathrm{C}$ until analyzed for the concentrations of IgG by RIA (Saskatoon Colostrum Co.) and bicarbonate concentrations (Prairie Diagnostic Services, University of Saskatchewan, Saskatoon, Canada) using a Hitachi analyzer (Hitachi 912 Automatic Analyzer; Roche Diagnostics, Quebec, Canada; Stockham and Scott, 2008).

Apparent efficiency of absorption at $24 \mathrm{~h}$ of age was estimated using the equation [plasma IgG $(\mathrm{g} / \mathrm{L}) \times \mathrm{BW}$ $(\mathrm{kg}) \times 0.09 / \mathrm{IgG}$ intake $\times 100 \%$ (Quigley and Drewry, 1998). The area under the curve (AUC) for serum samples at $0,6,12,24$, and $48 \mathrm{~h}$ was determined using the trapezoidal rule (Phillips and Taylor, 1973) with the equation $0.5 \times$ difference in time $\times$ difference in IgG or serum bicarbonate concentrations.

Data were analyzed as a randomized complete block design using the MIXED procedure of SAS (2001; SAS Institute Inc., Cary, NC). The 24-h serum concentrations of $\operatorname{IgG}$ and serum bicarbonate, AEA of IgG, and AUC of serum IgG and serum bicarbonate were fitted to the following model:

$$
\mathrm{Y}_{\mathrm{ij}}=\mu+\mathrm{B}_{\mathrm{i}}+\mathrm{S}_{\mathrm{j}}+\mathrm{E}_{\mathrm{ij}},
$$

where $\mathrm{Y}=$ the dependent variable, $\mu=$ the overall mean, $B_{i}=$ the random effect of block $\mathrm{i}(\mathrm{i}=1, \ldots, 13)$, $\mathrm{S}_{\mathrm{j}}=$ the fixed effect of the jth $\mathrm{NaHCO}_{3}$ level $(\mathrm{j}=0,15$, $30,45)$, and $\mathrm{E}_{\mathrm{ij}}=$ the residual error $\sim \mathrm{N}\left(0_{1} \sigma^{2}{ }_{\mathrm{e}}\right)$.

Degrees of freedom were calculated using the Kenward-Rogers option of the MIXED procedure of SAS (SAS Institute). Single degree of freedom contrasts for linear and quadratic effects were determined. Significant treatment effects were declared at $P \leq 0.05$ and trends at $0.05 \leq P \leq 0.10$. Block effect was not significant $(P>0.25)$ and was removed from the model for all variables.

Average BW of all calves at birth was $44.2 \pm 5.5 \mathrm{~kg}$. The $\mathrm{pH}$ of the $\mathrm{CR}$ used in the 4 treatments was 6.10 \pm 0.34 (control), $6.60 \pm 0.09$ (15-g treatment), 6.90 \pm 0.08 (30-g treatment), and $7.10 \pm 0.21$ (45-g treatment). At birth, the average serum IgG concentration for all calves was $0.5 \pm 0.7 \mathrm{~g} / \mathrm{L}$. During the initial feeding 4 calves were fed via esophageal feeder, 1 was given 2 feedings of $\mathrm{CR}$ on the control treatment, 1 calf was given 2 feedings of $\mathrm{CR}$ on the 15-g treatment, 3 calves

Table 1. Nutrient analysis of colostrum replacer and milk replacer $(\mathrm{DM} \text { basis })^{1}$

\begin{tabular}{lcc}
\hline Item & \multicolumn{1}{c}{ CR } & MR \\
\hline $\mathrm{CP}, \%$ & 55.3 & 21.4 \\
Fat, \% & 20.9 & 20.5 \\
Lactose, \% & 12.5 & 41.1 \\
Ca, \% & 0.95 & 1.01 \\
$\mathrm{P}, \%$ & 0.80 & 0.76 \\
$\mathrm{~K}, \%$ & 0.68 & 1.75 \\
$\mathrm{Mg}, \%$ & 0.13 & 0.15 \\
$\mathrm{Na}, \%$ & 0.28 & 0.87 \\
$\mathrm{Zn}, \mathrm{mg} / \mathrm{kg}$ & 75 & 113 \\
IgG, g/dose & $211.6^{2} / 216.8^{3}$ & - \\
\hline
\end{tabular}

${ }^{1} \mathrm{CR}=$ Land O'Lakes Colostrum Replacer (Saskatoon Colostrum Co., Saskatoon, SK, Canada); MR = Milk Replacer, nonmedicated (Blue Seal Feeds, Londonderry, NH).

${ }^{2}$ Calves $1-7$ were fed this concentration.

${ }^{3}$ Calves $8-52$ were fed this concentration. 
were given 2 feedings of $\mathrm{CR}$ on the $30-\mathrm{g}$ treatment, and 1 calf on the $45-\mathrm{g}$ treatment was fed CR via esophageal feeder.

Serum IgG concentrations at $24 \mathrm{~h}$ showed a negative linear trend $(P<0.08$; Table 2$)$ with increasing $\mathrm{NaH}-$ $\mathrm{CO}_{3}$ in the $\mathrm{CR}$. Of the 52 calves, 51 attained serum IgG concentration $\geq 10.0 \mathrm{~g} / \mathrm{L}$, indicating successful passive transfer. Area under the curve $(P=0.03)$ and AEA $(P$ $=0.05$ ) for serum concentration of IgG showed negative linear responses to increasing levels of $\mathrm{NaHCO}_{3}$ from 0 to $45 \mathrm{~g}$ (Table 2). These negative linear effects were driven by the $45-\mathrm{g}$ treatment, suggesting that at this level of supplementation calves may be experiencing metabolic alkalosis, decreasing their ability to absorb IgG (Figure 1). Elevated concentrations of serum bicarbonate can be associated with metabolic alkalosis or as a compensation for acidosis (Stockham and Scott, 2008). The AUC for serum concentration of bicarbonate in our study had a positive linear effect with increasing dietary levels of $\mathrm{NaHCO}_{3}$ (Table 2, Figure 2), which may reduce intestinal IgG uptake.

Eight calves had serum concentrations of $\operatorname{IgG} \geq 1 \mathrm{~g} / \mathrm{L}$ when blood samples were collected at $0 \mathrm{~h}(0.49 \pm 0.73$ $\mathrm{g} / \mathrm{L})$. Typically, calves are born with lower levels of IgG in their blood. However, abnormal placentation or a damaged placenta can result in transfer of maternal IgG to the fetus (Redman, 1979) or calves may produce IgG after transplacental or transcervical exposure to an infectious agent (Chigerwe et al., 2008). Even though the dams of our calves had no retained placentas, some damage to the placenta may have occurred. Calves exposed to infection in utero have shown increased serum IgG and IgM concentrations (Chigerwe et al., 2008), which may also explain the elevated serum IgG observed in the current study.
Morrill et al. (2010) observed higher $(P<0.05)$ 24-h serum IgG concentrations and higher AEA for calves receiving supplemental $\mathrm{NaHCO}_{3}$ compared with those that did not (IgG 16.3 vs. $13.2 \mathrm{~g} / \mathrm{L}$ and AEA 31.2 and $26.1 \%$, respectively). In the present study, AUC for IgG showed a negative linear response $(P=0.03)$ with increasing dietary $\mathrm{NaHCO}_{3}$ (Table 2). Conversely, Morrill et al. (2010) reported an increase in the AUC in calves supplemented with $\mathrm{NaHCO}_{3}$, which may be explained by differences in feeding protocols between studies. Morrill et al. (2010) fed CR in 2 feedings, providing 132 $\mathrm{g}$ of $\mathrm{IgG} \pm 19.5 \mathrm{~g}$ of $\mathrm{NaHCO}_{3}$ at the first feeding and $66 \mathrm{~g}$ of $\mathrm{IgG} \pm 9.75 \mathrm{~g}$ of $\mathrm{NaHCO}_{3}$ in the second feeding $6 \mathrm{~h}$ later. In the current experiment, 212 or $217 \mathrm{~g}$ of IgG (variation due to 2 lots of $\mathrm{CR}$ ) was fed with or without $\mathrm{NaHCO}_{3}$ supplementation at a single feeding (0-h feeding). Jaster (2005) observed that feeding calves 2 feedings consisting of $2 \mathrm{~L}$ of colostrum rather than one $4-\mathrm{L}$ feeding resulted in higher AEA levels and increased IgG absorption. The difference in IgG absorption reported by Jaster (2005) may be attributed to saturation of the intestinal absorptive capacity for IgG when feeding 4 $\mathrm{L}$ of colostrum at a single feeding. Therefore, it can be hypothesized that the single feeding of CR that provided $>200 \mathrm{~g}$ of IgG may have exceeded the intestinal capacity to absorb IgG suppressing any beneficial effect of $\mathrm{NaHCO}_{3}$ on enhancing IgG absorption.

Apparent efficiency of absorption of $\operatorname{IgG}$ at $24 \mathrm{~h}$ showed a negative linear response $(P=0.05)$ when the dietary levels of $\mathrm{NaHCO}_{3}$ were increased from 0 to $45 \mathrm{~g}$ (Table 2). The AEA of calves on the 45-g treatment was lowest overall, indicating that absorption was compromised in these calves. These results differ from those of Morrill et al. (2010), who observed an increase $(P<0.05)$ in AEA $(+5.1 \%)$ in calves supplemented

Table 2. Initial BW (mean $\pm \mathrm{SD}$ ), 24-h serum IgG concentrations, apparent efficiency of absorption ( $\operatorname{IgG}$ ), area under the curve (IgG), 24-h serum bicarbonate concentrations, and area under the curve (serum bicarbonate) of calves fed varying amounts of $\mathrm{NaHCO}_{3}$

\begin{tabular}{|c|c|c|c|c|c|c|c|}
\hline Item & \multicolumn{4}{|c|}{ Treatment $^{1}$} & $\mathrm{SE}$ & \multicolumn{2}{|c|}{ Contrast } \\
\hline Initial BW, kg & $42.8 \pm 4.4$ & $45.4 \pm 5.4$ & $42.4 \pm 5.0$ & $44.8 \pm 5.9$ & & & \\
\hline \multicolumn{8}{|l|}{ Serum IgG, g/L } \\
\hline $24 \mathrm{~h}$ & 16.9 & 16.0 & 17.2 & 14.5 & 0.75 & 0.08 & 0.22 \\
\hline Lowest $^{2}$ & 13.3 & 12.0 & 12.0 & 7.70 & & & \\
\hline Highest $^{3}$ & 20.1 & 18.5 & 23.1 & 18.8 & & & \\
\hline Serum bicarbonate, $\mathrm{mmol} / \mathrm{L}, 24 \mathrm{~h}$ & 29.0 & 31.7 & 33.0 & 33.1 & 4.67 & 0.28 & 0.49 \\
\hline AUC serum bicarbonate,${ }^{6} \mathrm{mmol} / \mathrm{L} \times \mathrm{h}$ & 1,277 & 1,405 & 1,466 & 1,475 & 25.6 & $<0.0001$ & 0.03 \\
\hline
\end{tabular}

${ }^{1}$ Treatments: Control $=0 \mathrm{~g}$ of $\mathrm{NaHCO}_{3} ; 15 \mathrm{~g}=15 \mathrm{~g}$ of $\mathrm{NaHCO}_{3} ; 30-\mathrm{g}=30 \mathrm{~g}$ of $\mathrm{NaHCO}_{3} ; 45-\mathrm{g}=45 \mathrm{~g}$ of $\mathrm{NaHCO}_{3}$.

${ }^{2}$ Lowest 24-h serum IgG concentration.

${ }^{3}$ Highest 24-h serum IgG concentration.

${ }^{4}$ Apparent efficiency of absorption: [plasma $\operatorname{IgG}(\mathrm{g} / \mathrm{L}) \times \mathrm{BW}(\mathrm{kg}) \times 0.09 / \mathrm{IgG}$ intake] $\times 100 \%$ (Quigley and Drewry, 1998).

${ }^{5}$ Area under the curve; $0.5 \times$ difference in time $\times$ difference in IgG concentration (Phillips and Taylor, 1973).

${ }^{6}$ Area under the curve; $0.5 \times$ difference in time $\times$ difference in serum bicarbonate concentration (Phillips and Taylor, 1973). 


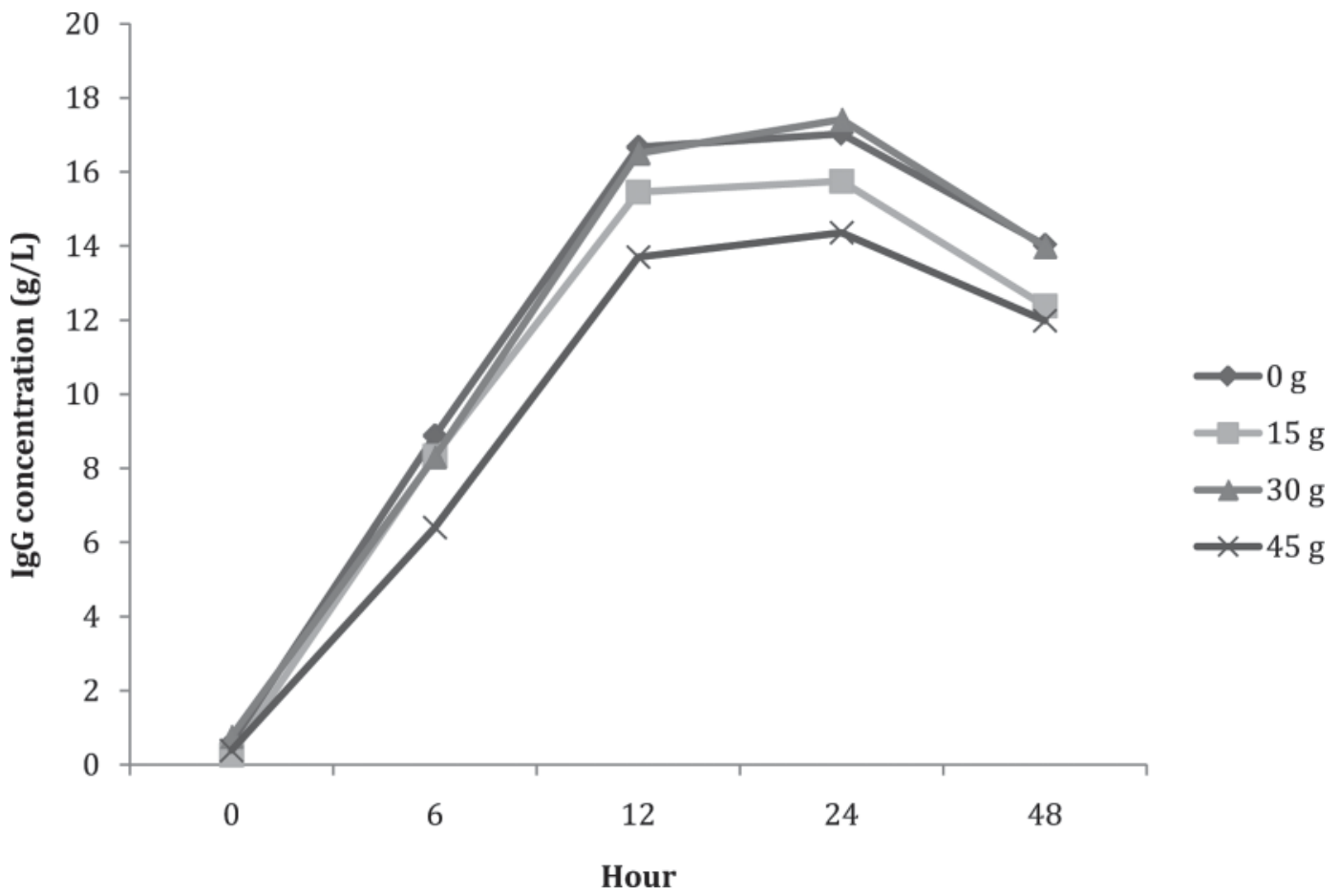

Figure 1. Serum IgG concentration for calves receiving $0,15,30$, or $45 \mathrm{~g}$ of $\mathrm{NaHCO}_{3}$ added to the colostrum replacer.

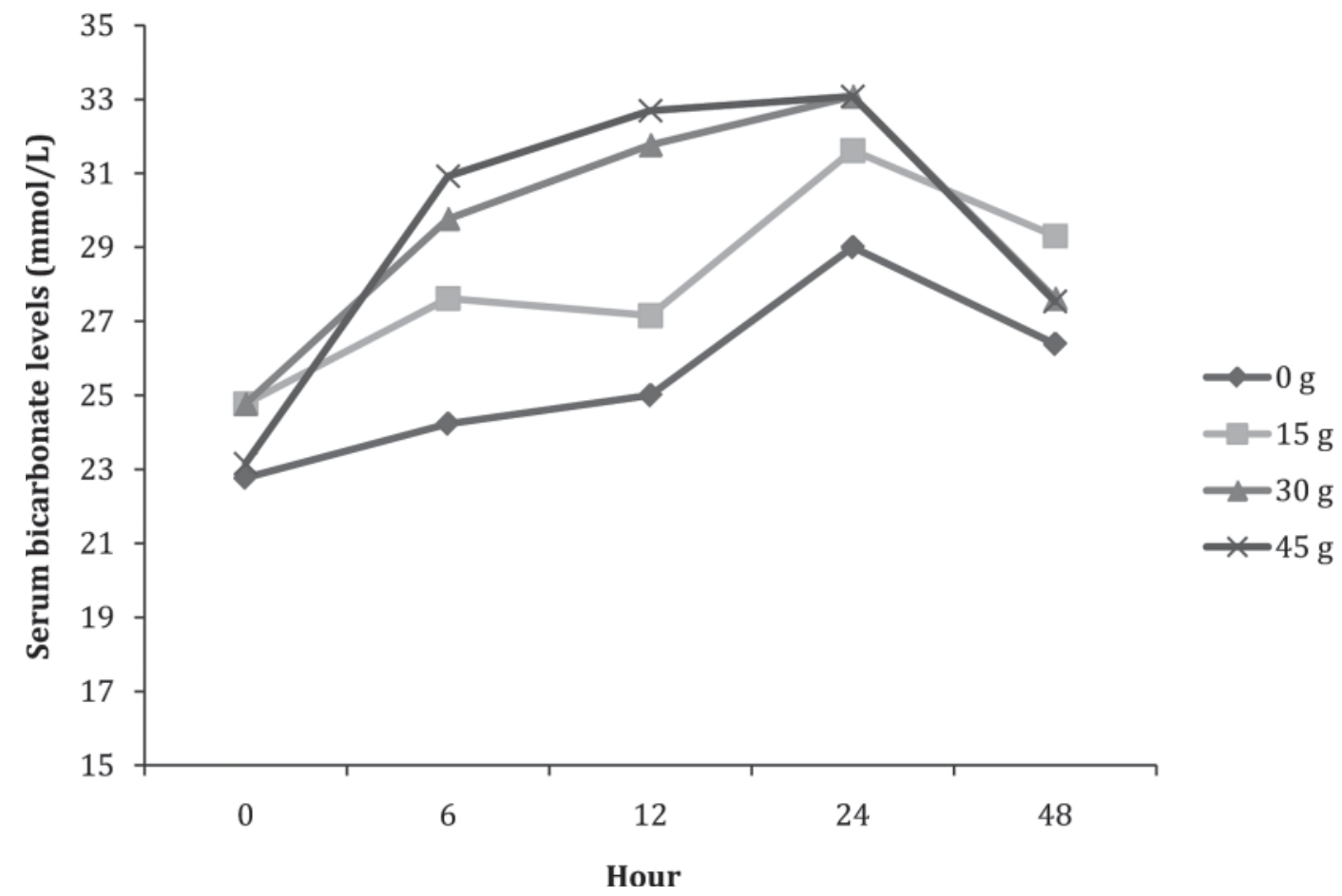

Figure 2. Serum bicarbonate levels for calves fed 0, 15, 30, or $45 \mathrm{~g}$ of $\mathrm{NaHCO}_{3}$ added to colostrum replacer. 
with $30 \mathrm{~g}$ of $\mathrm{NaHCO}_{3}$ compared with those with no supplementation.

The serum concentrations of bicarbonate were similar across treatments $($ mean $=32 \mathrm{mmol} / \mathrm{L})$, which may be explained by the body's physiological response to maintain homeostasis (Table 2). Our results are corroborated by data from the University of Saskatchewan showing that the physiological serum concentrations of bicarbonate for 3- to 7-yr-old dairy cattle range from 17 to $33 \mathrm{mmol} / \mathrm{L}$ (S. Myers, Prairie Diagnostic Services, University of Saskatchewan, Saskatoon, Canada; unpublished data).

In summary, adding incremental levels of $\mathrm{NaHCO}_{3}$ to $\mathrm{CR}$ had negative linear responses on the serum concentration of IgG, IgG AEA, and IgG AUC. Supplementing CR with $45 \mathrm{~g}$ of $\mathrm{NaHCO}_{3}$ resulted in the most detrimental effect on IgG absorption. Area under the curve for serum bicarbonate increased linearly with increasing amounts of dietary $\mathrm{NaHCO}_{3}$. Future research in this area should focus on feeding protocols with or without addition of $\mathrm{NaHCO}_{3}$ and their effects on IgG absorption, which would help to elucidate the efficacy of this supplement in different feeding regimens.

\section{ACKNOWLEDGMENTS}

The authors acknowledge Saskatoon Colostrum Company Ltd. (Saskatoon, Canada) for financial support, the donation of colostrum replacer, and $\operatorname{IgG}$ and serum bicarbonate assays. This project was supported by NC-1042 regional project. The authors also thank the Fairchild Teaching and Research Center (University of New Hampshire) staff for use of the calves and general animal husbandry. The authors also thank N. L. Whitehouse (University of New Hampshire, Durham) for assistance with statistical analysis of data.

\section{REFERENCES}

AOAC. 1995. Official Methods of Analysis. 15th ed. AOAC International, Arlington, VA.
AOAC. 2002. Official Methods of Analysis. 17th ed. AOAC International, Gaithersburg. MD.

Beam, A. L., J. E. Lombard, C. A. Kopral, L. P. Garber, A. L. Winter, J. A. Hicks, and J. L. Schlater. 2009. Prevalence of failure of passive transfer of immunity in newborn heifer calves and associated management practices on US dairy operations. J. Dairy Sci. 92:3973-3980

Bullen, J. J., H. J. Rogers, and L. Leigh. 1972. Iron-binding proteins in milk and resistance to Escherichia coli infections in infants. BMJ 1:69-75.

Butler, J. E. 1969. Bovine immunoglobulins: A review. J. Dairy Sci. $52: 1895-1909$

Chigerwe, M., J. W. Tyler, D. W. Nagy, and J. R. Middleton. 2008. Frequency of detectable serum IgG concentrations in precolostral calves. Am. J. Vet. Res. 69:791-795.

Eppard, P. J., D. E. Otterby, R. G. Lundquist, and J. G. Linn. 1982 Influence of sodium bicarbonate on growth and health of young calves. J. Dairy Sci. 65:1971-1978.

Foley, J. A., and D. E. Otterby. 1978. Availability, storage, treatment, composition, and feeding value of surplus colostrum: A review. J. Dairy Sci. 61:1033-1060.

Griffiths, E., and J. Humphreys. 1977. Bacteriostatic effect on human milk and bovine colostrum on Escherichia coli: Importance of bicarbonate. Infect. Immun. 15:396-401.

Jaster, E. H. 2005. Evaluation of quality, quantity, and timing of colostrum feeding on immunoglobulin $\mathrm{G}_{1}$ absorption in Jersey calves. J. Dairy Sci. 88:296-302.

Jenny, B. F., S. E. Hodge, G. D. O'Dell, and J. E. Ellers. 1984. Influence of colostrum preservation and sodium bicarbonate on performance of dairy calves. J. Dairy Sci. 67:313-318.

Morrill, K. M., S. P. Marston, N. L. Whitehouse, M. E. Van Amburgh, C. G. Schwab, D. M. Haines, and P. S. Erickson. 2010. Anionic salts in the prepartum diet and addition of sodium bicarbonate to colostrum replacer, and their effects on immunoglobulin G absorption in the neonate. J. Dairy Sci. 93:2067-2075.

NAHMS. 2007. Colostrum feeding and management on U.S. Dairy Operations, 1991-2007. Accessed Sep. 18, 2010. http://nahms.aphis. usda.gov/dairy/dairy07/Dairy_colostrum.pdf.

Phillips, G. M., and T. J. Taylor. 1973. Theory and Application of Numerical Analysis. Academic Press, New York, NY.

Quigley, J. D. III, and J. J. Drewry. 1998. Nutrient and immunity transfer from cow to calf pre- and postcalving. J. Dairy Sci. 81:2779-2790

Redman, D. R. 1979. Prenatal influence on immunocompetance of the neonate. J. Anim. Sci. 49:258-267.

Smith, G. W., and D. M. Foster. 2007. Absorption of protein and immunoglobulin $\mathrm{G}$ in calves fed a colostrum replacer. J. Dairy Sci. 90:2905-2908.

Stockham, S. L., and M. A. Scott. 2008. Fundamentals of Veterinary Clinical Pathology. 2nd ed. Iowa State Press, Ames. 